\title{
Tren Program Tahfidz Al-Qur'an sebagai Metode Pendidikan Anak
}

\author{
Ajeng Wahyuni \\ Institut Agama Islam Negeri (IAIN) Ponorogo \\ Jl. Ki Hajar Dewantara 15A Iring Mulyo Kota Metro Lampung \\ e-mail: ajengwahyuni77@gmail.com \\ Akhmad Syahid \\ Institut Agama Islam Negeri Metro \\ Jl. Ki Hajar Dewantara 15A Iring Mulyo Kota Metro Lampung \\ e-mail: ahmadsyahid19@yahoo.co.id
}

Revised: 19 May 2019;

Accepted: 31 May 2019

\begin{abstract}
The introduction of memorizing Al-Qur'an or also called Tahfidz Al-Qur'an is one of the leading programs of schools both public schools and private schools. Although in the beginning the Tahfidz Al-Qur'an program was not or less desirable either by education managers or even people and students. However, now the Tahfidz Al-Qur'an program has proven to be one of the flagship programs of schools. Even by implementing the Tahfidz Al-Qur'an program, many of these schools are sought after and are in demand. This study raises the advantages of the Tahfidz Al-Qur'an program carried out by schools which later became favorite schools, large schools and even the Tahfidz Al-Qur'an Program which is commonly displayed in banners, billboards, student admission pamphlets new with the highest order then followed by other excellent programs. For parents of students, sending children to educational institutions that carry out the Tahfidz AlQur'an program is a pride. They have dreams of their children becoming Muhafidz Al-Qur'an who will guide them and put crowns of gold on the Day of Judgment.
\end{abstract}

Keywords: tahfidz program, children's education, primary school

\begin{abstract}
Abstrak
Pengenalan menghafal Al-Qur'an atau disebut juga Tahfidz Al-Qur'an merupakan salah satu program unggulan sekolah-sekolah baik sekolah yang berstatus sekolah Negeri maupun Sekolah Swasta. Meskipun pada awalnya program Tahfidz Al-Qur'an tidak atau kurang diminati baik oleh pengelola pendidikan atau pun orang tuda dan siswa. Namun, sekarang program Tahfidz Al-Qur'an terbukti menjadi salah satu program unggulan sekolah-sekolah. Bahkan dengan menerapkan program Tahfidz Al-Qur'an, banyak sekolah-sekolah tersebut yang banyak dicari dan diminati. Penelitian ini mengangkat tentang kelebihan-kelebihan dari program Tahfidz Al-Qur'an yang dilaksanakan oleh sekolah-sekolah yang kemudian menjadi sekolah favorit, sekolah besar dan bahkan Program Tahfidz Al-Qur'an biasa dimunculkan di Banner-banner, baliho, pamphlet
\end{abstract}


penerimaan siswa baru dengan urutan paling atas kemudian disusul program-progam unggulan lain. Bagi orangtua siswa, menyekolahkan anak pada lembaga pendidikan yang melaksanakan program Tahfidz Al-Qur'an adalah sebuah kebanggan. Mereka mempunyai mimpi kelak anakanak mereka menjadi para Muhafidz AL-Qur'an yang akan menuntun mereka dan memakaikan mahkota dari emas pada hari kiamat kelak.

Kata kunci: program tahfidz, pendidikan anak, sekolah dasar

\section{Pendahuluan}

Pendidikan pada anak usia dini merupakan pendidikan yang sangat vital, dan harus dilakukan dengan cara yang terbaik, karena pada masa ini merupakan masa untuk membentuk karakter, kreatifitas, belajar memecahkan masalah dan masa untuk melatih daya ingat. Meskipun pada dasarnya setiap anak lahir dalam keadaan fitrah (suci), namun dalam masa pertumbuhannya setiap anak membutuhkan pendidikan untuk menjadi pribadi yang bermoral, kreatif dan mandiri. Cakupan ruang pendidikan bagi anak meliputi pendidikan dalam keluarga, lingkungan dan sekolah. Sehingga pendidikan tidak hanya berlangsung di lembaga-lembaga pendidikan formal saja, namun dimanapun anak berada disitulah tempat pendidikannya.

Kewajiban awal untuk mendidik anak berada pada kedua orangtua, sehingga orangtua harus memiliki ilmu dalam mendidik anak. Orangtua harus mengetahui tahapan-tahapan dalam mendidik anak. Salah satu tokoh yang menjadi figure dalam mendidik anak adalah Luqman.

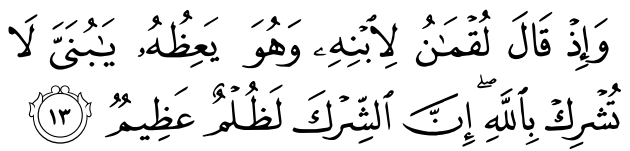

"dan (ingatlah) ketika Luqman berkata kepada anaknya, di waktu ia memberi pelajaran kepadanya: «Hai anakku, janganlah kamu mempersekutukan Allah, Sesungguhnya mempersekutukan (Allah) adalah benar-benar kezaliman yang besar». (QS. Luqman ayat 13). ${ }^{1}$

${ }^{1}$ Kementerian Agama Republik Indonesia, Al-Kamal Al-Qur'an Tajwid Warna, Transletirasi Per Kata, Terjemah Per Kata (Jakarta Pusat: Pustaka jaya
Namun demikian, hampir semua orangtua tidak sendirian dalam mendidik anak-anaknya. Baik orangtua yang tidak terikat dengan lembaga tempat bekerja maupun orangtua yang terikat waktu dengan lembaga tempat bekerja. Hal ini terjadi karena orangtua menyadari bahwa mendidik anak merupakan hal penting yang harus dilakukan dengan cara yang hati-hati, focus, serius dan memperhatikan metodemetodenya. Terkhusus untuk anak-anak usia dini yang masih polos dan lucu. Jika perlakuan pendidikan kurang tepat atau mungkin salah, maka akan berdampak fatal terhadap anak, dan tentunya orangtua pun ikut merasakan dampaknya.

Taman Pendidikan Anak Usia Dini (PAUD) dan Sekolah Dasar (SD) merupakan lembaga pendidikan untuk anak-anak sekaligus sebagai rumah kedua bagi mereka untuk mengembangkan potensi, belajar beradaptasi dengan dunia luar, mengenal berbagai macam karakter dan belajar berkomunikasi dengan teman-teman sebaya serta bermain. Tentu permainan yang disediakan disekolah merupakan permainan yang ramah anak dan tetap diawasi selama bermain. Disamping itu, permainan yang disediakan oleh lembaga harus memiliki fungsi untuk membantu pertumbuhan fisik maupun psikis anak, dengan bahasa lain permainan edukatif.

Dalam ranah dunia pendidik formal, khususnya pendidik untuk anak usia dini dan Sekolah Dasar (SD), mengalami pertumbuhan yang sangat membanggakan.

Ilmu, 2016). h. 412 
Disamping itu, lembaga-lembaga pendidikan formal seperti Taman Pendidikan Anak Usia Dini (PAUD), Sekolah Dasar (SD) telah mengalami pergeseran dan kemajuan dari segi metode pengajaran. Disamping karena tuntutan dari Kementerian Pendidikan yang mengharuskan setiap sekolah harus meningkatkan kreatifitas tenaga pendidik, agar pendidikan menjadi bermutu. Karena kewajiban lembaga pendidikan mengadakan dan melaksanakan pendidikan yang bermutu, disamping itu pendidikan yang bermutu merupakan hak setiap warga Negara. Hal ini berdasarkan Sisdiknas No. 20 tahun 2003 Bab IV pasal $5 .^{2}$

Disamping itu kepentingan lembaga pendidikan untuk bisa memberikan pelayanan yang terbaik bagi peserta didik. Lembaga-lembaga pendidikan terus melakukan peningkatan pelayanan pendidikan diantaranya dengan melakukan penambahan jam tambahan, peningkatan kreatifitas dalam mengajar dan penambahan kegiatan ekstra kurikuler yang mampu membantu peningkatan kecerdasan, kreatifitas peserta didik dan bakat.

Begitu juga dengan lembaga pendidikan non formal, seperti Taman Pendidikan Al-Qur'an (TPA) yang merupakan lembaga pendidikan non formal paling tua yang mengajarkan khusus ilmu agama Islam (Diniyah) ; membaca al-Qur'an, ibadah shalat, puasa, akhlak dan lain sebagainya, berusaha meningkatkan kualitas pengajarannya dengan berusaha meningkatkan dalam menghafal Al-Qur'an. Tahfidz Al-Qur'an di Taman Pendidikan Al-Qur'an (TPA) bukan hal baru, karena merupakan salah satu bidang ilmu yang diajarkan keapda santrinya, namun kebanyakan Taman Pendidikan Al-Qur'an (TPA) yang para santri

${ }^{2}$ Indra Keswara, "PENGELOLAAN PEMBELAJARAN TAHFIDZUL QUR'AN (MENGHAFAL AL QUR'AN) DI PONDOK PESANTREN AL HUSAIN MAGELANG," Hanata Widya 6, no. 2 (2017). h. 63 kebanyakan anak usia sekolah Taman Kanakkanak (TK) sampai anak Sekolah Dasar (SD) hanya menekankan menghafal pada suratsurat pendek yang terdapat pada Juz Amma (juz 30) dan surat-surat pilihan. Sekarang, tahfidzul Qur'an menjadi hal yang sangat diminati baik lembaga pendidikan forman dan non formal, orang tua dan anak sebagai peserta didik.

Dalam sejarah dan perkembangan menghafal Al-Qur'an di Indonesia mulai mengalami perkembangan pesat pasca pelaksanaan Musabaqah Hifdzil Qur'an pada tahun 1981. Yang pada mulanya hanya pulau Sulawesi dan jawa yang eksis dalam melaksanakan program tahfidz Al-Qur'an, setelah Musabaqah Hifdzil Qur'an tahun 1981 mulai menyebar kepulau-pulau yang ada di Indonesia, kecuali pulau Papua. ${ }^{3}$

Penerapan program tahfidz Al-Qur'an di lembaga-lembaga pendidikan formal seperti di sekolah-sekolah, seolah menjadi hal baru dan sangat unik. Hal ini disebabkan label sekolah secara umum focus pada bidang-bidang keilmuan Saint murni, kalau pun ada pelajaran agama mungkin hanya ada 2 jam sampai 4 jam dalam sepekan. Sebuah alokasi waktu yang jauh dari standar cukup jika yang hendak dicapai adalah ilmu dan amal. Karena ilmu agama harus dipelajari dan juga diimplementasikan.

\section{Urgensi Tahfidzul Qur'an Bagi Kecerdasan Anak}

Tugas orangtua dalam mendidik anak adalah wajib, pendidikan yang mampu melahirkan anak/generasi yang sadar akan tugasnya sebagai khalifah dimuka bumi. Diantara tugas khalifah adalah memelihara, merawat alam beserta isinya, melaksanakan tugas sebagai Makhluq, yaitu mengabdikan

${ }^{3}$ Nurul Hidayah, "Strategi Pembelajaran Tahfidz Al-Qur'an di Lembaga Pendidikan," Ta'allum 4, no. 1 (2016): 19. h.64 
diri kepada Rabb Pencipta Alam Semesta, berbakti kepada orangtua dan berbuat baik kepada seluruh makhluk yang ada di alam raya ini.

Salah seorang sahabat Nabi Muhammad Shalallahu'alaihi wa Sallam, yang bernama Abdullah bin Umar Radhiallahu'anhuma berpesan:

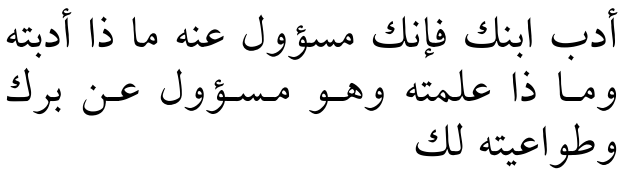

"Didiklah anakmu, karena sesungguhnya engkau akan dimintai pertanggungjawaban mengenai pendidikan dan pengajaran yang telah engkau berikan kepadanya. Dan dia juga akan ditanya mengenai kebaikan dirimu kepadanya serta ketaatannya kepada dirimu."

Program tahfidz Al-Qur'an sangat berperan dalam membantu pengembangan potensi anak, dimana potensi harus digali, dicari dan dikembangkan. ${ }^{4}$ Pencarian dan pengembangan potensi anak harus dimulai sejak usia dini, baik potensi berfikir kritis, potensi daya ingat, potensi kemampuan mengolah kata dan potensi-potensi lain yang ada pada anak.

Tahfidz atau menghafal merupakan sebuah usaha untuk mengulang atau melafazkan sesuatu tanpa berpikir lama. Dalam kamus Besar Bahasa Indonesia, menghafal diartikan sebagai sebuah usaha meresapkan ke dalam pikiran agar selalu ingat. ${ }^{5}$ Dalam susunan bahasa Arab, kata Tَفِفًَ - يَحْفَظُ حفًْْ - yang artinya selalu ingat dan sedikit lupa, dengan demikian Tahfidz

${ }^{4}$ Zulfitria, "PEMBELAJARAN TAHFIDZ AL-QURAN DALAM PENDIDIKAN KARAKTER ANAK USIA DINI (PAUD) ZULFITRIA," Jurnal Ilmiah Pendidikan Anak usia Dini 1, no. 2 (2016): 21. h. 48

${ }^{5}$ Ana Retnoningsih Suharso, Kamus Besar Bahasa Indonesia (Semarang: CV. Widya Karya, 20115).h. 160 lawan dari kata lupa. ${ }^{6}$ Menghafal merupakan aktivitas yang harus dilakukan secara continue dan penuh kesabaran, karena menghafal proses untuk menyatukan sebuah ilmu kedalam akal ingatan dan puncaknya menyatu pada diri pribadi penuntutnya.

Tahfidz atau hifzh memiliki arti menjaga, menghafal dan memelihara. Orang yang melakukan upaya menghafal atau selalu menjaga hafalannya dinamakan al-Hafizh atau Muhafizh. Menjaga atau memelihara sebuah ilmu mempunyai banyak ungkapan, diantaranya membaca al-Qur'an dengan cepat dan jitu (Zharul Lisan) dengan hafalan diluar kepala (Zhahrul Qolbi).

Suryabrata berpendapat bahwa menghafal adalah usaha sungguh-sungguh mencamkan sesuatu dengan penuh kesadaran dan disengaja. Lebih lanjut Suryabrata berpendapat bahwa hal-hal yang bisa membantu seseorang untuk menghafal adalah ;

1. Menghafal dengan cara membaca jahr. Maksudnya ketika sedang menghafal seseorang hendaknya membaca dengan bersuara (Jahr) tidak dibaca didalam hati. Karena hal ini akan lebih efektif dalam menghafal.

2. Pengaturan waktu dalam menambah hafalan. Dalam proses menghafal hal yang baik dilakukan untuk menambah hafalan adalah dengan menambah hafalan sedikit demi sedikit dan dilakukan secara rutin.

3. Penggunaan metode yang tepat dalam menghafal. Menghafal adalah usaha yang dilakukan dengan durasi waktu yang tidak singkat dan membutuhkan kesungguhan. Maka dalam menghafal

${ }^{6}$ Mahmud Yunus, Kamus Arab Indonesia (Jakarta: Hidakarya Agung, 1990).h. 105 
harus menggunakan metode yang tepat. $^{7}$

Proses yang dialami dalam menghafal adalah proses yang dilakukan secara totalitas oleh seluruh anggota badan, dari mata, telinga, lisan dan pikiran. Rutinitas dalam menghafal Al-Qur'an akan mempengaruhi pertumbuhan dan perkembangan anak. Baik dari segi intelektual/kecerdasan anak, emosional dan spiritualnya. Seorang anak yang membiasakan diri untuk menghafal AlQur'an akan mengalami perkembangan pola pikir yang baik dan perkembangan akhlak yang mulia.

Bagi perkembangan kecerdasan secara intelektual anak, menghafal menjadi salah satu metode untuk melatih kecerdasan dan daya ingatnya. Dimana pada usia dini fitrah seorang anak masih suci, bersih belum banyak terkotori oleh hal-hal negative. Aktivitas yang pasti dilakukan ketika menghafal adalah membaca, mengulang bacaan dan menyimpan bacaan-bacan yang pernah atau sudah dihafalkan. ${ }^{8}$ Bagi anak-anak, membaca adalah hal yang menyenangkan, baik bagi yang baru bisa membaca atau bagi yang sudah lancar membaca. Dengan demikian kesempatan ini harus dimaksimalkan untuk mengajarkan kepada anak untuk membaca kalam-kalam Allah yaitu ayat Al-Qur'an. Jika sejak usia dini anak diajarkan untuk suka membaca ayat-ayat Al-Qur'an, maka anak akan terjaga dari membaca hal-hal negative. Selama proses menghafal al-Qur'an saat itulah anak sedang melakukan proses penanaman Al-Qur'an pada dirinya, sehingga ketika Al-Qur'an sudah menyatu dalam jiwa dan ingatannya, maka akan diteruskan penyatuan Al-Qur'an dalam tindak dan tingkah lakunya.

\footnotetext{
${ }^{7}$ Fattah Hidayat, “Kajian Psikologi Pembelajaran Hafal Quran bagi Anak Usia Dini," 2017, 12. h. 279

${ }^{8}$ Hidayat.h, 83
}

Melalui kegiatan menghafal AlQur'an pada anak, akan menumbuhkan dan meningkatkan kecerdasan spiritual anak. Karena Al-Qur'an adalah sumber ketenangan hati, penentram jiwa. Hati Muhafidz (penghafal) Al-Qur'an tidak akan pernah kosong karena selalu digunakan untuk selalu membaca dan mengulang AlQur'an, sehingga hatinya menjadi lurus, bersih dan senantiasa tertambat kepada sang Pencipta Allah SWT. Rasulullah Muhammad Shalallahu'alaihi wa Sallam bersabda sebagaimana yang diriwayatkan oelh Abu Hurairah Radhiyallahu'anhu:

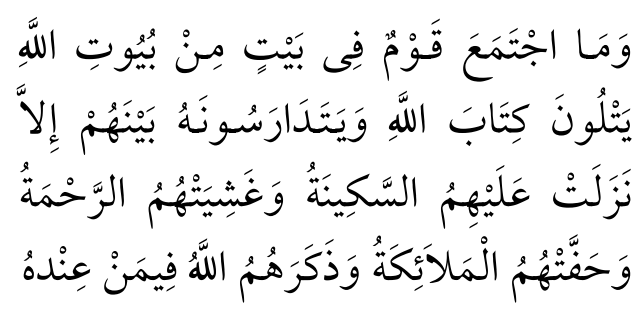

"Tidaklah suatu kaum berkumpul di salah satu rumah Allah membaca Kitabullah dan saling mengajarkan satu dan lainnya melainkan akan turun kepada mereka sakinah (ketenangan), akan dinaungi rahmat, akan dikeliling para malaikat dan Allah akan menyebut-nyebut mereka di sisi makhluk yang dimuliakan di sisi-Nya." (HR. Muslim, no. 2699). ${ }^{9}$

Pembiasaan menghafal Al-Qur'an yang dimulai dari aktivitas membaca, mengingat dan mengulang yang dilakukan oleh anakanak, juga menghasilkan sebuah interaksi dan komunikasi dengan pembuat Kalam yaitu Allah Subhanahu wa Ta'ala, huruf demi huruf, ayat demi ayat merupakan rangkaian kalimat-kalimat dzikir untuk mengingat Dzat Yang Maha Agung. Dengan perbuatan ini, maka anak juga telah melakukan usaha meningkatkan kecerdasan spiritualnya dan akan merasakan kehadiran Allah Subhanahu wa Ta'ala, dimana dan kapan pun dia berada. Dia akan bertindak dan berbuat sesuai

${ }^{9}$ https://rumaysho.com/12717-ketenanganjiwa-dalam-majelis-ilmu.html 
dengan keridhoan Penciptanya, karena kecerdasan spiritualnya menuntunnya untuk berbuat yang baik- baik. ${ }^{10}$

Kecerdasan spiritual pada anak dapat dilihat dari indikator-indikator sebagai berikut:

\section{Selalu merasa diawasi Allah SWT}

Anak yang cerdas secara spiritual akan cerdas secara ruhiyah, selalu merasa diawasi oleh Allah Subhanahu wa Ta'ala, dimanapun dan kapanpun berada. Kecerdasan spiritual menghasilkan salah satu produk keyakinan kepada Dzat Yang Maha Pencipta yang selalu mengawasi para hamba-hambaNya. Ketika akan melakukan sebuah perbuatan, kecerdasan spiritualnya akan membimbingnya untuk melakukan halhal yang baik, dan akan menolak perbuatanperbuatan maksiat. ${ }^{11}$

Meskipun pada dasarnya setiap manusia memiliki fitrah kecenderungan menyukai pada hal-hal yang baik dan membenci hal-hal yang buruk. Namun fitrah tersebut bisa saja hilang jika tidak dirawat dan dipelihara. Fitrah kepada hal yang positif membutuhkan perawatan dan bimbingan. Cara merawat dan melestarikan fitrah kecintaan pada hal-hal yang baik dapat dilakukan dengan meningkatkan hubungan kepada sang Pencipta, Allah Subhanahu wa Ta'ala, hal ini juga sering disebut Muraqabah. Kecerdasan spiritual juga akan memjadikan seorang anak akan menjaga lisan dari mengucapkan perkara-perkara yang negatif. Lisannya hanya akan mengucapkan sebuah kebenaran, jika tidak mampu mengucapkan maka lisan itu akan diam, hal ini ditopang

${ }_{10}$ Akhmad Muhaimin Azzat, Mengembangkan Kecerdasan Spiritual Bagi Anak (Jakarta: Ar-Ruzz Media, 2014).h. 52

11 Toto Tasmara, Kecerdasan Ruhaniah, (Transendental Intelligence), Membentuk Kepribadian Yang Bertanggung Jawab, Profesional Dan Berakhlak (Jakarta: Gema Insani, 2001). h. 14 oleh bimbingan baginda Rasul Muhammad Shalallahu'alaihi wa Sallam,

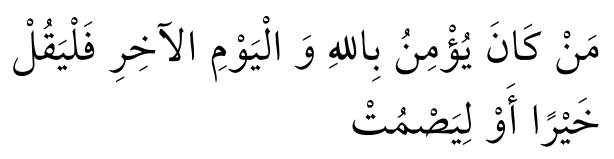

"Siapa yang beriman kepada Allah dan hari akhir, hendaklah dia berkata baik atau hendaknya dia diam."

Seorang anak yang telah menghafal Al-Qur'an memiliki rasa Khouf (takut) kepada Allah Subhanahu wa Ta'ala, dan perasaan selalu diawasi Allah Subhanahu wa Ta'ala, jangankan pada hal yang sifatnya lahiriyah, sampai pada hal yang sifatnya batiniyah pun dia akan merasa bahwa Allah Subhanahu wa Ta'ala, mengetahuinya. Dia yakin bahwa apa yang dia pikirkan dan rencana apa yang akan dilakukan telah diketahui Allah Subhanahu wa Ta'ala.

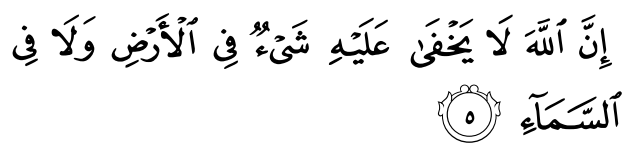

"Sesungguhnya bagi Allah tidak ada satupun yang tersembunyi di bumi dan tidak (pula) di langit." (QS. Ali Imron : 5). ${ }^{12}$

Inilah kelebihan pertama bagi anak yang memiliki kecerdasan spiritual yang diperoleh melalui usaha menghafal Al-Qur'an, hati-hati dalam berpikir dan bertindak, tegas menolak kemunkaran dan siap melaksanakan amar ma'ruf.

2. Memiliki rasa suka menolong kepada sesama

Kecerdasan spiritual pada anak terwujud dalam sebuah pembuktian sikap suka menolong sesama manusia. Kebarakahannya dari menghafal Al-Qur'an menumbuhkan rasa empati yang akan membawa anak memiliki kemampuan

12 Kementerian Agama Republik Indonesia, AlKamal Al-Qur'an Tajwid Warna, Transletirasi Per Kata, Terjemah Per Kata. 
merasakan kondisi batin orang lain. ${ }^{13}$ Dia menyadari bahwa sebagai manusia memiliki kewajiban untuk saling membantu sesama manusia sebagai makhluk yang diciptakan oleh Dzat yang Suka Menolong. Motivasi untuk melakukan ta'awun kepada orang lain didasarkan pada firman-firman Allah Subhanahu wa Ta'ala, diantaranya surat Al-Maidah ayat 2, surat Al-Anfal ayat 27, surat Al-Kahfi ayat 19 dan surat Ali Imron ayat 110 .

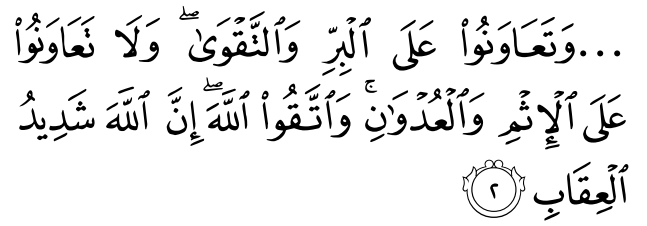

“... dan tolong-menolonglah kamu dalam (mengerjakan) kebajikan dan takwa, dan jangan tolong-menolong dalam berbuat dosa dan pelanggaran. dan bertakwalah kamu kepada Allah, Sesungguhnya Allah Amat berat siksa-Nya." (QS. Al-Maidah :2). ${ }^{14}$

3. Memiliki rasa tanggung jawab

Tumbuhnya rasa tanggungjawab pada anak yang menghafal Al-Qur'an berangkat dari kebiasaan mereka untuk menjaga hafalan-hafalannya. Para Muhafidz (penghafal) Al-Qur'an tidak hanya menghafal huruf-huruf hijaiyah saja, namun mereka menghafal harokat-harokat, hukum tajwid, ayat dan bahkan letak-letak huruf, ayat dan awal surat. Muhafidz tidak mungkin akan merubah atau meninggalkan atau sengaja melupakan bagian-bagian ayat yang telah mereka hafal, mereka akan berusaha semaksimal mungkin untuk menjaga dan mengingat bagian-bagian ayat.

${ }^{13}$ Toto Tasmara, Kecerdasan Ruhaniah, (Transendental Intelligence), Membentuk Kepribadian Yang Bertanggung Jawab, Profesional Dan Berakhlak. h. 30

14 Kementerian Agama Republik Indonesia, AlKamal Al-Qur'an Tajwid Warna, Transletirasi Per Kata, Terjemah Per Kata.
Dari sinilah para penghafal Al-Qur'an belajar untuk memiliki rasa tanggungjawab terhadap amanah yang dibebankan kepada mereka. Setiap amanah atau perbuatan yang dilakukannya pasti akan mendapat balasan dari Allah Subhanahu wa Ta'ala, ${ }^{15}$

4. Memiliki sifat jujur

Kecerdasan spiritual yang dihasilkan dari menghafal Al-Qur'an tercermin pula melalui tumbuhnya rasa atau sikap jujur. Sikap jujur merupakan salah satu sikap baik atau akhlak al-karimah yang menjadi cirri seorang muslim. Ahlak-akhlak baik akan menjadi sebuah kebiasaan jika dilakukan secara kontinu.

Para penghafal Al-Qur'an akan membiasakan diri untuk selalu berbuat baik, sehingga perbuatan-perbuatan yang dilakukan akan terjadi secara spontan, perbuatan baik dilakukan tanpa susah payah dan tidak banyak menemukan kesulitan. ${ }^{16}$

Pesan moral dalam mengulang bacaan bagi anak adalah untuk melatih melakukan hal-hal yang baik dan bermanfaat bagi diri mereka. Kepolosan dan kesucian anak harus diisi dengan hal-hal yang positif. Dengan membiasakan anak untuk mengulang bacaan al-Qur'an, berarti telah mengajarkan anak untuk menjaga otensitas kesucian al-Qur'an. Hal ini berdasarkan firman Allah SWT ;

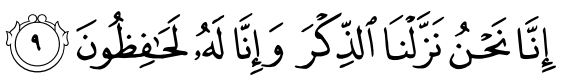

"Sesungguhnya Kami-lah yang menurunkan Al Quran, dan Sesungguhnya Kami benarbenar memeliharanya". ${ }^{17}$

Pengajaran menghafal Al-Qur'an kepada anak-anak bermanfaat bagi anak

15 M. Abdul Qadir Abu Faris, Menyucikan Jiwa, Terj. Habiburrahman Saerozi (Jakarta: Gema Insani, 2006). h. 306

16 Dian Andayana Abdul Majdi, Pendidikan Karakter Perspektif Islam (Bandung: Rosda Karya, 2013). h. 128

17 Ayat ini memberikan jaminan tentang kesucian dan kemurnian Al Quran selama-lamanya. 
dalam rangka melatih daya ingat dan melatih untuk memiliki pemikiran yang cemerlang. Karena sejak usia anak-anak mereka sudah dilatih untuk selalu memutar otaknya agar hafalannya tidak hilang atau lupa. ${ }^{18}$ Dengan melakukan hal ini, secara tidak langsung juga telah mengajarkan kepada anak untuk teliti, hati-hati dan melatih cepat mengerti dan mampu membedakan lanjutan-lanjutan ayat antar surat yang satu dengan surat yang lain. Anak yang sudah terbiasa menghafal Al-Qur'an akan memiliki kemampuan untuk mengingat pelajaran-pelajaran lain. Karena menghafal Al-Qur'an sama saja menghafal wahyu-wahyu Allah SWT yang mengandung Mukjizat.

Secara psikologis, anak yang dibiasakan atau terbiasa menghafal AlQur'an akan memiliki zasa cinta pada AlQur'an yang lebih dibanding anak-anak yang kurang dalam menghafal Al-Qur'an. Hal ini disebabkan anak yang terbiasa menghafal Al-Qur'an akan lebih banyak berinterksi baik dengan cara memegang, membawa dan membaca yang kemudian dilanjutkan dengan mengingat tulisan-tulisan ayat per ayat sampai letak dan khot (gaya) tulisan Al- Qur'an.

\section{Tahfidz Sebagai Program Unggulan Sekolah}

Program Tahfidz Al-Qur'an merupakan salah satu program yang banyak dikembangkan dan diunggul-unggulkan di lembaga-lembaga pendidikan khususnya di jenjang tingkat Sekolah Dasar (SD) akhirakhir ini. Meskipun berdasarkan kurikulum pendidikan nasional, Tahfidz Al-Qur'an tidak disebutkan secara khusus untuk dijadikan sebagai program unggulan. Tahfidz AlQur'an muncul atas dasar ide kreatif dari para pengelola sekolah. Lebih jauh, dalam

18 Hidayat, "Kajian Psikologi Pembelajaran Hafal Quran bagi Anak Usia Dini.” H. 85 sejarah Tahfidz Al-Qur'an di Indonesia muncul dari perorangan yang belajar menghafal Al-Qur'an pada guru tertentu dan lembaga-lembaga pendidikan non-formal seperti Pondok Pesantren yang memiliki guru yang merupakan Muhafidz Al-Qur'an. ${ }^{19}$ Diantara pondok pesantren yang memulai perintisan pembelajaran Tahfidz adalah pondok pesantren Krapyak (Al-Munawir) yang berada di Provinsi Yogyakarta dan pondok Pesantren Al-Hikmah di Benda Bumiayu. ${ }^{20}$

Pondok pesantren Al-Amin Seputih Banyak, salah satu lembaga Pendidikan di Kabupaten Lampung Tengah yang berangkat dari pendidikan non-formal dengan focus pendidikan Diniyah Amm, tanpa ada program khusus Tahfidz. Dalam perjalanannya, pondok pesantren Al-Amiin Seputih Banyak kurang diminati oleh masyarakat. Pada tahun 2015 mendirikan program pendidikan formal dengan salah satu program unggulan Tahfidz Al-Qur'an. ${ }^{21}$ Dengan mengadakan musyawarah bersama para wali santri, usulan dan dukungan untuk penguatan program Tahfidz Al-Qur'an mendapat respon positif dari wali santri.

Sekolah Dasar (SD) Muhammadiyah Metro, sebagai sekolah yang berlabel swasta namun jumlah muridnya melebihi Sekolah Dasar lain yang berlabel Negeri. Salah satu program unggulannya adalah Tahfidz Al-Qur'an, hal ini nampak dari kegiatan belajar mengajar dan di jadwal pelajaran memasukan Tahfidz Al-Qur'an, dan setiap tahun melakukan wisuda akbar Tahfidz AlQur'an. Begitu juga Sekolah Dasar Islam Terpadu (SDIT) Wahdatul Ummah, sekolah dasar dengan status swasta yang mempunyai program unggulan Tahfidz Al-Qur'an yang

${ }^{19}$ http://www.baq.or.id/2018/02/sejarahperkembangan-pengajaran-tahfidz.html

${ }^{20}$ Ibid

${ }^{21}$ Arsip Pondok Pesantren Al-Amiin Seputih Banyak. 
berada di Kota Metro, termasuk sekolah dasar yang dengan jumlah murid banyak dan sangat diminati masyarakat.

Program Tahfidz Al-Qur'an, yang pada mulanya tidak menarik dan kurang diminati oleh lembaga-lembaga pendidikan formal, pada era pendidikan sekarang ini telah menunjukkan dan terbukti menjadi salah satu program unggulan sekolah yang banyak diminati atau menjadi daya tarik dalam penerimaan calon siswa baru. Para orangtua wali siswa mulai menyadari bahwa pentingnya memasukkan anak pada sekolah yang mengajarkan al-Qur'an terlebih sampai menghafal Al-Qur'an.

Menurut Rui Zainal Fanani ada beberapa alasan mengapa sekolah-sekolah Islam perlu melaksanakan program Tahfidz Al-Qur'an, diantaranya adalah :

1. Program Tahfidz Al-Qur'an dapat mengangkat brand sekolah Islam yang lebih unggul dibanding sekolah umum, dimana sekolah umum masih mengunggulkan program-program pelajaran umum saja.

2. Program Tahfidz Al-Qur'an mampu meneguhkan komitmen beriman kepada Allah Subhanahu wa Ta'ala, para penyelenggara dan pengelola sekolah Islam dengan kecintaanya kepada Al-Qur'anul Karim.

3. Program Tahfidz Al-Qur'an merupakan program unggulan yang memiliki peluar besar dalam mengungguli lembaga-lembaga pendidikan umum yang lainnya, serta menjadi daya tarik tersendiri bagi masyarakat untuk menyekolahkan anak-anaknya di sekolah Islam.

4. Dengan menyelenggarakan program Tahfidz Al-Qur'an, membuktikan bahwa keluarga besar lembaga pendidikan penyelenggara meyakini terhadap kemukjizatan Al-Qur'an, mudah dihafal, meningkatkan kecerdasan berpikir dan mampu melembutkan hati. ${ }^{22}$

\section{Simpulan}

Tahfidz Al-Qur'an merupakan sebagai program pengamalan keagamaan bagi ummat muslim yang mendapatkan apresiasi khusus dan balasan atau imbalan khusus dari Allah Subhanahu wa Ta'ala. Berbagai kenikmatan, kemudahan dan kemulyaan hidup bagi hafidz Al-Qur'an baik ketika masih hidup di dunia bahkan sampai kehidupan akhirat menjadi motivasi tersendiri bagi mereka yang ingin menghafal Al-Qur'an. Keutamaan para penghafal Al-Quran diantaranya; ditemani para malaikat Allah, diberikan kesempatan memakaikan mahkota kepada kedua orangtuanya diakhirat kelak, mendapatkan syafaat Al-Qur'an dan lain lagi. Sedangkan keutamaan semasa hidup didunia diantaranya; dimudahkan urusanya oleh Allah Subhanahu wa Ta'ala, diberikan ketenangan dan kebarakahan hidup, dal lain sebagainya.

Keuntungan bagi lembaga pendidikan baik formal maupun non-formal yang menyelenggarakan program Tahfidz AlQur'an diantaranya adalah semakin diminati oleh para wali dan siswa dan diberikan keberhasilan dalam menyelenggarakan proses pendidikan. Meskipun program Tahfidz Al-Qur'an tidak diwajibkan oleh Pemerintah dalam hal ini dibawah wewenang Kementerian Pendidikan dan Kebudayaan, namun program Tahfidz Al-Qur'an membuktikan bahwa dengan program ini sangat menguntungkan baik bagi sekolah penyelenggara, orangtua siswa, lingkungan dan pemerintah. Karena dengan mengikuti program tahfidz Al-Qur'an, anak-anak selain 
cerdas secara intelektual, anak juga cerdas secara emosional dan cerdas secara spiritual. Akhlak pergaulan sehari-hari menunjukkan ahlak yang terpuji.

Berbagai upaya dilakukan oleh para penggiat dan pengelola lembaga pendidikan yang memiliki program Tahfidz Al-Qur'an, mulai dari mengikuti atau mengadakan sendiri Dauroh atau Pelatihan menghafal, mengirim tenaga pengajar dan siswa untuk mengikuti kursus menghafal Al-Qur'an sampai upaya memilih metode-metode menghafal Al-Qur'an yang cepat, tepat dan menyenangkan. Bahkan sampai menyediakan kelas khusus untuk penghafal Al-Qur'an. Hal itu semua dilakukan dengan tujuan agar program tahfidz Al-Qur'an bisa tercapai dan mendapatkan hasil yang memuaskan sesuai standar yang telah ditentukan.

\section{Daftar Pustaka}

Abdul Majdi, Dian Andayana. Pendidikan Karakter Perspektif Islam. Bandung: Rosda Karya, 2013.

Akhmad Muhaimin Azzat. Mengembangkan Kecerdasan Spiritual Bagi Anak. Jakarta: Ar-Ruzz Media, 2014.

Hidayat, Fattah. "Kajian Psikologi Pembelajaran Hafal Quran bagi Anak Usia Dini," 2017, 12.

Indra Keswara. "PENGELOLAAN PEMBELAJARAN TAHFIDZUL QUR'AN (MENGHAFAL AL QUR'AN) DI PONDOK PESANTREN AL HUSAIN MAGELANG." Hanata Widya 6, no. 2 (2017).

Kementerian Agama Republik Indonesia. Al-Kamal Al-Qur'an Tajwid Warna, Transletirasi Per Kata, Terjemah Per Kata. Jakarta Pusat: Pustaka jaya Ilmu, 2016.
M. Abdul Qadir Abu Faris. Menyucikan Jiwa, Terj. Habiburrahman Saerozi. Jakarta: Gema Insani, 2006.

Mahmud Yunus. Kamus Arab Indonesia. Jakarta: Hidakarya Agung, 1990.

Nurul Hidayah. "Strategi Pembelajaran Tahfidz Al-Qur'an di Lembaga Pendidikan." Ta'allum 4, no. 1 (2016): 19.

Suharso, Ana Retnoningsih. Kamus Besar Bahasa Indonesia. Semarang: CV. Widya Karya, 20115.

Toto Tasmara. Kecerdasan Ruhaniah, (Transendental Intelligence), Membentuk Kepribadian Yang Bertanggung Jawab, Profesional Dan Berakhlak. Jakarta: Gema Insani, 2001.

Zulfitria. "PEMBELAJARAN TAHFIDZ ALQURAN DALAM PENDIDIKAN KARAKTER ANAK USIA DINI (PAUD) ZULFITRIA." Jurnal Ilmiah Pendidikan Anak usia Dini 1, no. 2 (2016): 21.

https://slideplayer.info/slide/12233671/

Arsip Pondok Pesantren Al-Amiin Seputih Banyak.

http:/ / www.baq.or.id/2018/02/ sejarahperkembangan-pengajaran-tahfidz. html. 